\title{
UPPER CAMBRIAN BASAL CONGLOMERATE OF THE KALLAVERE FORMATION ON THE PAKRI PENINSULA, NW ESTONIA
}

\author{
Jüri NEMLIHER ${ }^{a}$ and Ivar PUURA ${ }^{a, b}$
}

2 Geoloogia Instituut (Institute of Geology), Estonia pst. 7, EE-0001 Tallinn, Eesti (Estonia)

b Institutionen för Geovetenskap, Uppsala Universitet (Institute of Earth Sciences, Uppsala University), Dept. of Historical Geology and Palaeontology, Norbyvägen 22, S-75236 Uppsala, Sverige (Sweden)

Presented by E. Pirrus

Received 8 June 1995, accepted 10 October 1995

Abstract. On the Pakri Peninsula up to $0.5 \mathrm{~m}$ thick lenses of basal conglomerate at the base of the Kallavere Formation overlie the sandstones of the Lower Cambrian Tiskre Formation. The Upper Cambrian age of the conglomerate has been established by lingulate brachiopods Ungula convexa and $U$. ingrica in the conglomerate and conodonts of the Cordylodus proavus Zone in the overlying beds of the Kallavere Formation. The conglomerate comprises pebbles and cobbles derived mostly from the Tiskre Formation, but occasionally from recycled Upper Cambrian sediments. Observations and XRD studies of authigenic pyrite, marcasite, and apatite occurring in cement suggest the exposure of the conglomerate to reduced environments during early diagenesis.

Key words: sedimentary conglomerate, authigenic minerals, XRD, SEM, pyrite, marcasite, apatite, brachiopods, Upper Cambrian, Pakri Peninsula, Estonia.

\section{INTRODUCTION}

In northern Estonia, the base of the Upper Cambrian-Lower Ordovician Kallavere Formation overlying unconformably the Lower Cambrian, is usually marked with a distinct basal conglomerate. The main constituents of the conglomerate are the valves and shell fragments of obolid brachiopods and phosphatized sandstone pebbles. From section to section, the composition of the conglomerate is highly variable; in some sections it is lacking (е.g., Хейнсалу, 1987; Heinsalu, 1990).

The occurrences of conglomerates in the Cambrian-Ordovician boundary beds extend eastwards to the Syas' River, $150 \mathrm{~km}$ east of St. Petersburg, Russia (Мююрисепп, 1958; Попов et al., 1989), and westwards to Oland Island and Siljan District, Dalarna, Sweden (Hadding, 1927; Puura \& Holmer, 1993).

(C) Eesti TA Toimetised. Geoloogia, 1996 
The westernmost exposures of the conglomerate in Estonia located on the Pakri Peninsula are of considerable interest for interpreting the sedimentary environments and dating the marine transgressions in the Baltic region during the Cambrian-Ordovician transition. The present paper describes the basal conglomerate of the Kallavere Formation on the Pakri Peninsula. Our study complements a paper on the CambrianOrdovician boundary beds in the Pakri Cape section (Mens et al., 1996) where the details on the location of the section, geological setting, and stratigraphy can be found.

\section{ANALYTICAL METHODS}

The lenses of the basal conglomerate of the Kallavere Formation, with the maximum thickness of $0.5 \mathrm{~m}$, are distributed unevenly along the more or less continuous exposure of the Cambrian-Ordovician boundary beds on the NE coast of the Pakri Peninsula. The conglomerate lenses were sampled from six locations. For mineralogical studies by means of X-ray diffraction analysis (XRD) and scanning electron microscopy (SEM), a total of 12 samples representing a spectrum of different lithologies, e. g., pebbly conglomerate (samples N102A, B), indurated, cemented conglomerate (samples N103A, B, C), and cement (samples N104/1, 2), were taken. Preserved shells of lingulate brachiopods were collected for further identification.

Part of the samples selected for SEM studies was etched with $6 \%$ $\mathrm{HCl}$. Both untreated and etched samples were polished or fractured, coated with gold and studied by means of SEM (Tesla equipment, $18 \mathrm{KV}$ ).

The phosphate samples selected for the XRD studies were powdered in an agate mortar. The powder samples were studied by means of X-ray diffractometer HZG-4 (Germany) using Fe-filtered Co-radiation $(\lambda=$ $1.788965 \AA)$ in a step-scan mode (10 s exposure for each point, with $0.02^{\circ}$ step). Two series of the intensities of the apatite reflections: $002,102,210,211,112,300,202$ and $113,222,312,213,321,410,402,004$ were registered in two different output files. The lattice parameters were calculated by the least squares' method from the measured intensities fitted with Lorenzian distribution. The reflection angles were corrected against quartz reflections 101 and 112 . The $\mathrm{CO}_{3}$ content in apatite was calculated according to the empirical equation provided by Schuffert et al. (1990).

\section{LITHOLOGY AND MINERALOGY}

The clastic sediments of the Kallavere Formation overlying the sandstones of the Lower Cambrian Tiskre Formation crop out along the onshore cliff on the Pakri Peninsula. The lowermost part of the Kallavere Formation is characterized by the presence of up to $0.5 \mathrm{~m}$ thick lenses of both phosphate- and pyrite-cemented basal conglomerate.

This conglomerate comprises mainly dark-coloured pebbles, cobbles, and boulders reaching $40 \mathrm{~cm}$ in diameter. The space between the pebbles and cobbles is filled with sand and clay particles and lingulate brachiopod valves and shell fragments. This sandy-clayey matrix is cemented by authigenic apatite, pyrite, marcasite, and occasionally, calcite. The conglomerate is overlain by a kerogenous shale bed (Mens et al., 1996). 
Two kinds of the basal conglomerate lenses can be distinguished: (1) dark-coloured flat pebbles and cobbles, cemented with pyrite, apatite, and carbonates in sandy-clayey matrix (Figs. 1,2) occurring as a single bed in the bottom of the depressions; (2) loose cobbles and boulders of the Tiskre sandstones without pyrite or phosphate impregnation in friable sands or weakly-cemented sandstone matrix of the Kallavere Formation occurring in higher areas of the unconformity surface. As the latter type of conglomerate has been described and figured by Müürisepp (Мююрисепп, 1958, Fig. 1, p. 57), we restrict our description to the first type.

The conglomerate of the first type (Fig. 2) contains pebbles and cobbles of different composition and origin. Larger flattened and mostly dark-coloured cobbles of the Cambrian sandstone are cemented by both pyrite and phosphate. Most cobbles have fine-grained sandstone matrix showing close lithological similarity to the underlying Lower Cambrian Tiskre sandstone. However, some cobbles are composed of slightly coarser sandstone; occasionally, they yield fragments of the lingulate brachiopod Ungula sp. Individual sand grains have often a well-developed outer pyritized rim (Fig. 3). Light-coloured, subrounded to rounded reworked pebbles are 0.4 to $1 \mathrm{~cm}$ in diameter (Fig. 2). All reworked particles are cemented with several generations of pyrite, phosphate, and carbonates. In the pyritized pebbles and cobbles burrows, less than $2 \mathrm{~mm}$ in diameter, can be observed (Fig. 4).

The phosphatic cement of the pebbles and cobbles is mostly represented by structureless mass filling intergranular space. SEM studies reveal that sand grains may be covered by a phosphatic film (Fig. 5), whereas on cut sections the characteristic radial structure of apatite crystallites can be observed (Fig. 6). Some problematic features resembling the remnants of organic framework (probably phosphatized bacterial cells; Fig. 7) and fragments of phosphatized filaments are observed in cement (Fig. 8).

X-ray diffractometry shows close mineral composition for all the studied samples consisting of quartz, apatite, pyrite, and calcite. Marcasite has been found from three samples. The lattice parameters of these minerals appear to be constant while the other properties (crystallinity and linear intensities) are highly variable (Fig. 9).

The study of eight samples of apatite in cement revealed remarkably stable apatite lattice parameters $a$ and $c$ ranging from 9.331 (1) to $9.332(2) \AA$ and from $6.888(0)$ to $6.888(2) \AA$, respectively. These values are characteristic of carbonate fluorapatite (McConnell, 1973), with the $\mathrm{CO}_{3}$ content (calculated after Schuffert et al., 1990) from 5.2 to 5.6 wt $\%$.

\section{BIOSTRATIGRAPHICAL AGE}

Lingulate brachiopods Ungula convexa and Ungula ingrica identified in the conglomerate matrix are characteristic of the Upper Cambrian of Estonia (Mens et al., 1993). The overlying beds of the Kallavere Formation are dated by conodonts as belonging to the Cordylodus proavus Zone (Mens et al., 1996). Thus, the tentative time for the formation of the conglomerate at the base of the Kallavere Formation on the Pakri Peninsula can be estimated as Late Cambrian, not later than the Cordylodus proavus time. 


\section{LITHOGENESIS}

\section{Origin of pebbles and matrix components}

The lithological and structural investigation of the coarse clastic material from the basal conglomerate of the Kallavere_Formation indicates that most of the reworked clastics derived from the underlying cemented and lithified Tiskre sandstone beds which were ripped up (probably in the below wave base environment) by the recurrent highly agitated hydrodynamic regime. Still, some of the cobbles, yielding fragments of Ungula sp., suggest that lithified Upper Cambrian source rocks have also been recycled and incorporated to the conglomerate.

In northern Estonia, lingulate brachiopod valves and fragments are characteristic components of the basal conglomerate, usually forming coquinas containing occasional small pebbles. In the conglomerate on the Pakri Peninsula, the share of the lingulate skeletal material is relatively small. The coquinas have patchy distribution. Roundedness of the shells suggests their hydrodynamic transport and accumulation at some distance from brachiopod habitats.

\section{Aspects of authigenic mineralization and diagenesis}

Among authigenic minerals pyrite, marcasite, and carbonate fluorapatite occur in cement and cover the surface of the matrix components of the conglomerate; calcite occurs in cement.

The formation of authigenic iron disulphides, pyrite, and marcasite is considered to be initiated by sulphate-reducing bacteria producing hydrogen sulphide by decomposing organic matter (Berner, 1984). Recent experimental studies imply that formation through nucleation and subsequent sulphidation of an iron monosulphide precursor is the dominant mechanism of the iron disulphide precipitation in low temperature sediments, while direct nucleation and precipitation of $\mathrm{FeS}_{2}$ from aqueous solutions is apparently not common (Schoonen \& Barnes, 1991a, 1991b).

Amorphous FeS, precipitated by reaction between aqueous $\mathrm{H}_{2} \mathrm{~S}$ and $\mathrm{Fe}^{2+}$, is subsequently converted to an iron disulphide. The reaction path in the conversion of amorphous $\mathrm{FeS}$ depends on the $\mathrm{pH}$. In most experiments above pH 6, subsequent conversion of amorphous FeS to pyrite via mackinawite $(\mathrm{FeS})$ and greigite $\left(\mathrm{Fe}_{3} \mathrm{~S}_{4}\right)$ has been observed. Interpreting their experimental results, Schoonen \& Barnes (1991b) suggested that based on the crystal structures a conversion of greigite to marcasite is more likely than to pyrite; hence a possible conversion of greigite to pyrite via marcasite should be considered.

The occurrence of marcasite documented in experiments below pH 6 and its predominance below $\mathrm{pH} 4$ have been interpreted by Schoonen \& Barnes (1991b) as the result of a higher growth rate for marcasite than for pyrite, attributed to protonated polysulphides repelled from a growing pyrite surface but attracted to a growing marcasite surface (Murowchick \& Barnes, 1986). Rakovan et al. (1995), describing epitaxial overgrowths of marcasite on pyrite, suggested that reconstruction of the pyrite surface to the marcasite structure and continued growth of marcasite would negate the need for marcasite nucleation, significantly reducing the activation barrier to its formation. Metastable with respect to pyrite, at ambient temperatures, marcasite may persist for millions of years (Lennie \& Vaughan, 1992).

Whereas pyritization of sandstone pebbles postdates burrow formation, it can be concluded that reducing conditions formed aiter the reworking of sandstone pebbles into the basal conglomerate. Considering that the 


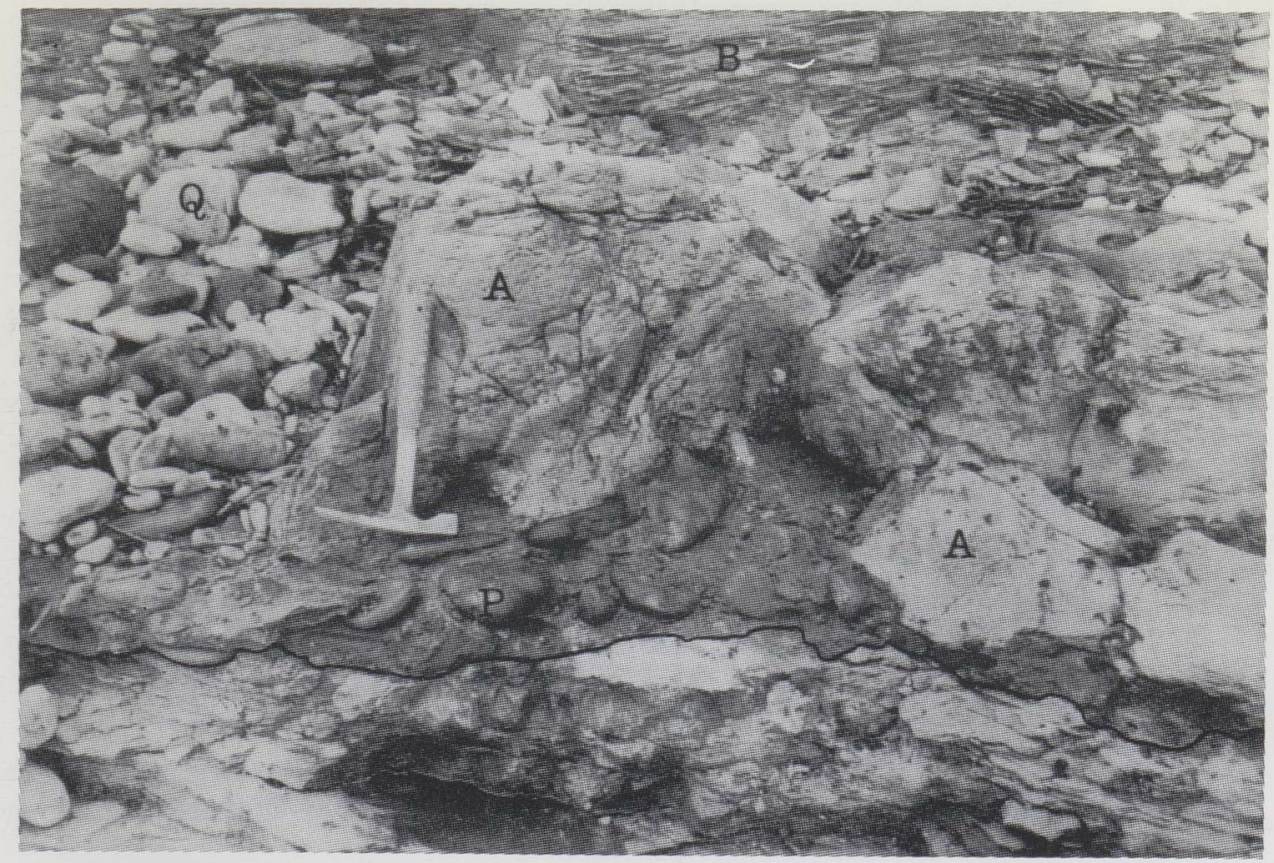

Fig. 1. Conglomerate at the base of the Kallavere Formation underlain by the sandstones of the Tiskre Formation. $A$, sandstone boulders from the Tiskre Formation; $B$, kerogenous shale; $P$, pyrite- and phosphate-cemented cobbles; $Q$, Quaternary deposits of the Baltic Sea yielding the cobbles derived mostly from Ordovician limestones. Photo by Jaak Nōlvak.

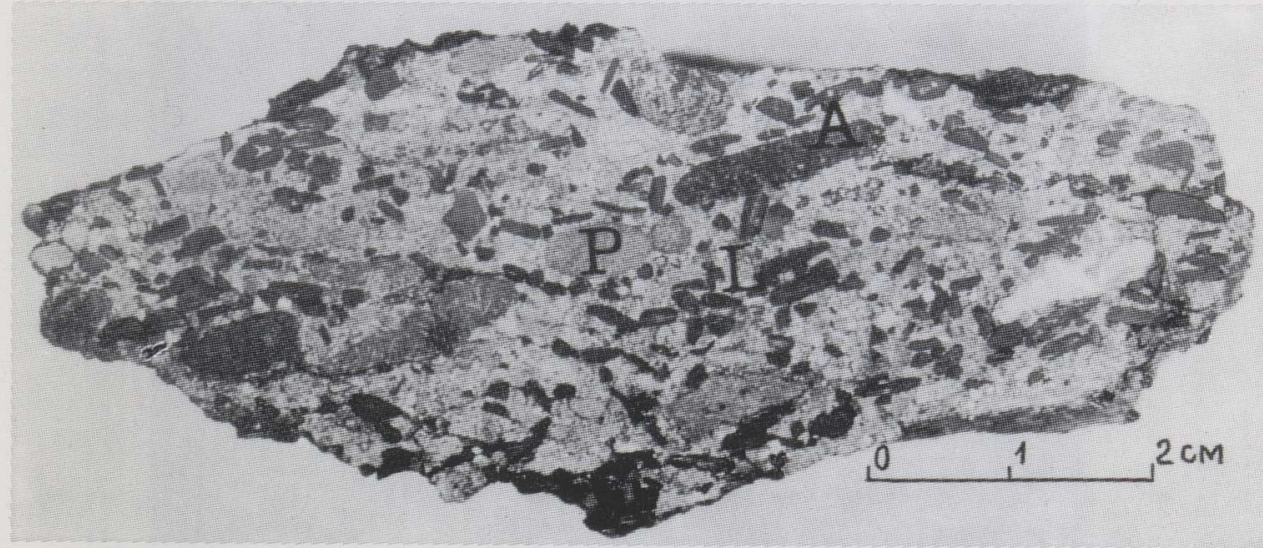

Fig. 2. Sample N103B, the polished, unetched surface of a cobble. $A$, phosphatized pebbles; $L$, lingulate brachiopod fragments; $P$, pyritized pebbles. 


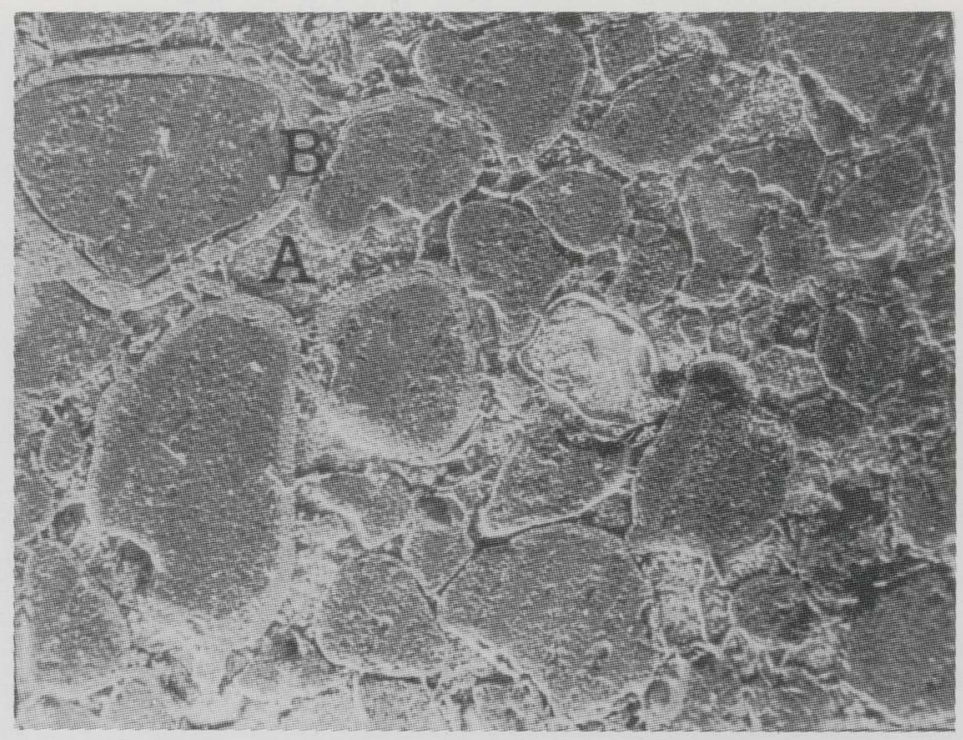

Fig. 3. Sample N103C, SEM micrograph of the polished and etched $(6 \% \mathrm{HCl})$ surface of the cement inside a cobble. Pyritized rims $(B)$ surround the quartz grains which are cemented by phosphate (A). $\mathrm{x} 130$.

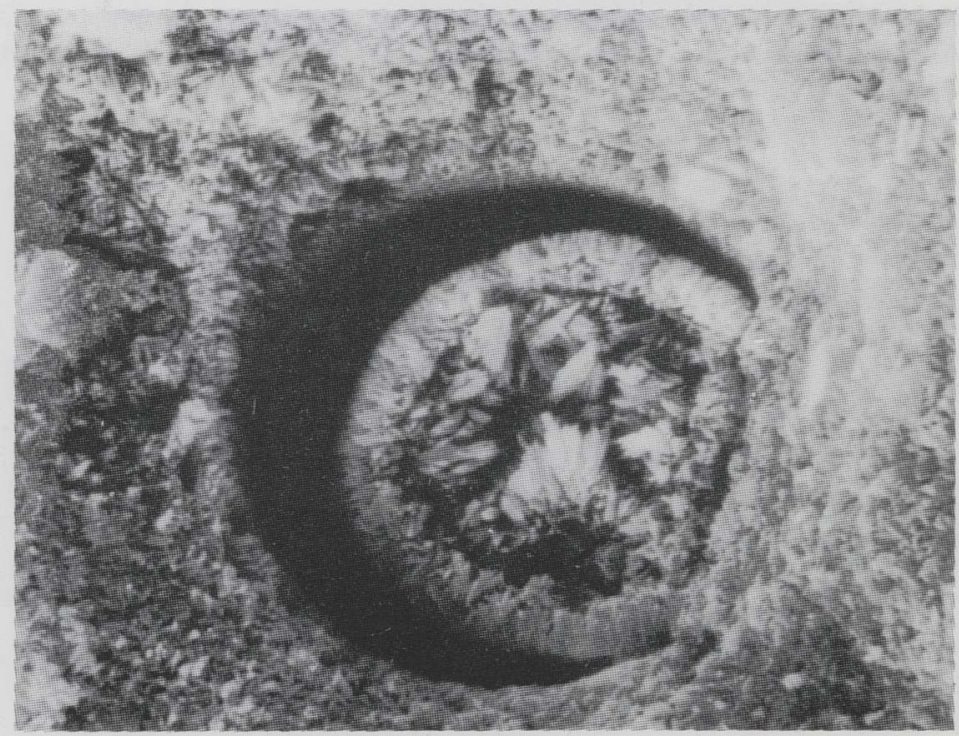

Fig. 4. Sample N102B, SEM micrograph of the polished and etched $(6 \% \mathrm{HCl})$ surface of a pyritized cobble. A microboring in the pyritized surface. $\mathrm{x} 4500$. 


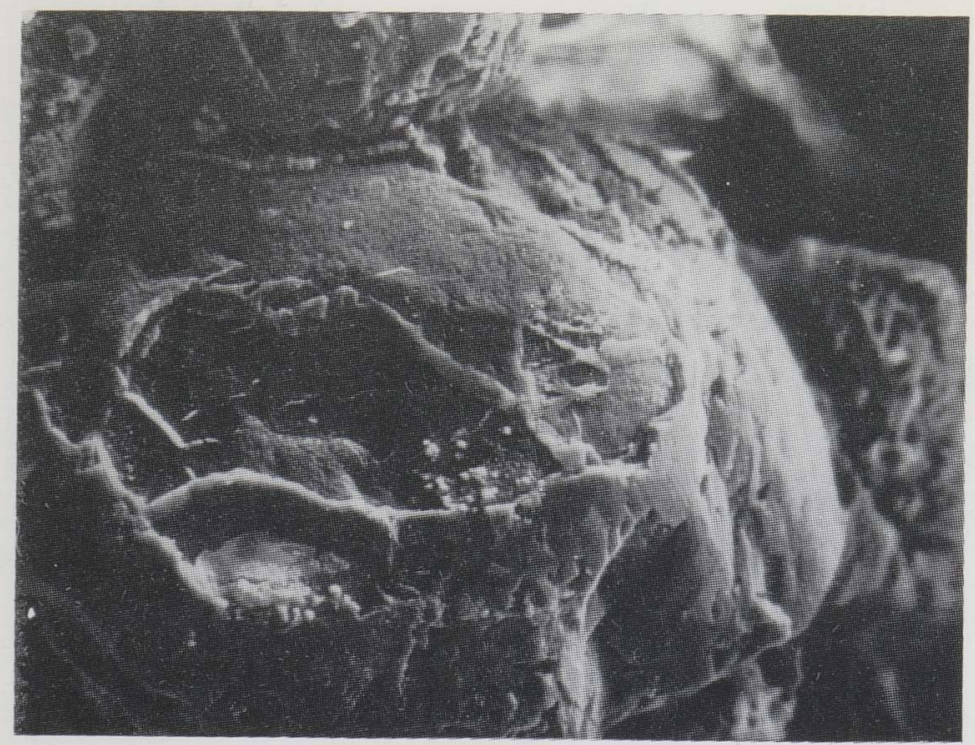

Fig. 5. Sample N104/2, SEM micrograph of the broken surface of phosphatic cement in the conglomerate. Note the phosphatic film covering the sand grains. $\mathrm{x} 800$.

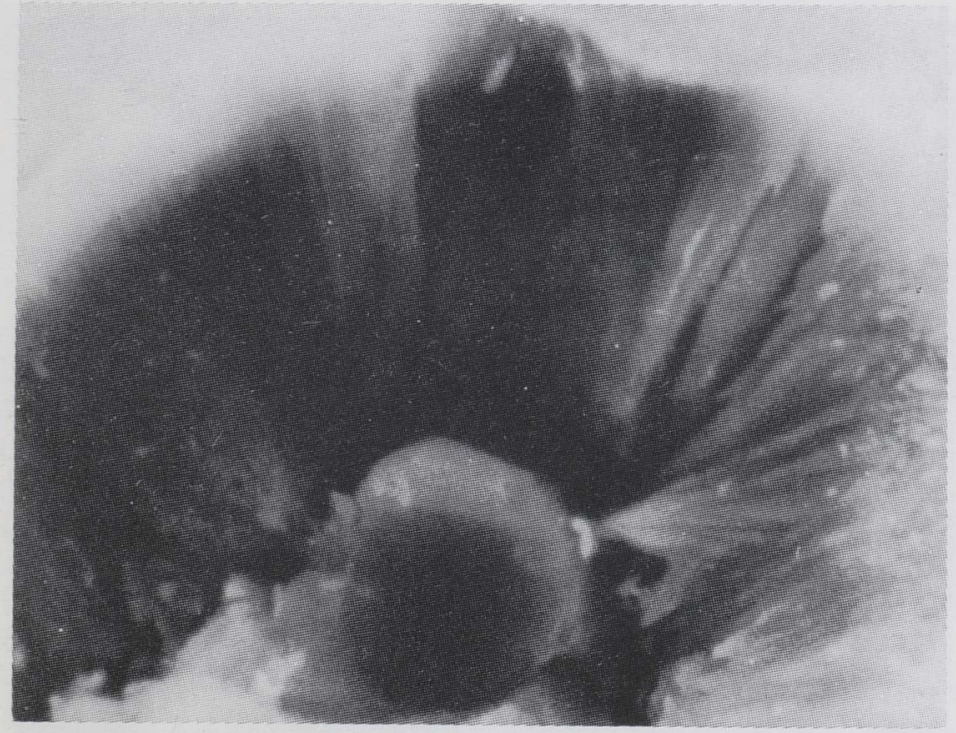

Fig. 6. A detail of Fig. 5. Radial crystallite aggregates of a phosphatic film. x7000. 


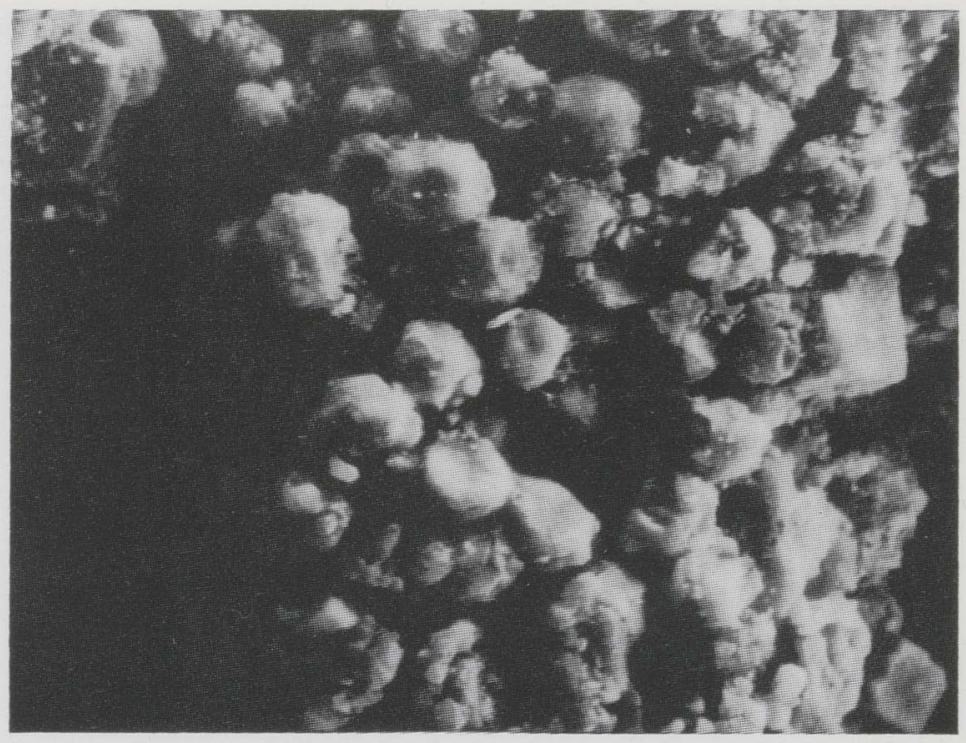

Fig. 7. Sample N102/1, SEM micrograph of a broken untreated surface of phosphatic cement in the conglomerate. Possible microbial structures, consisting of carbonate fluorapatite. $\times 3000$.

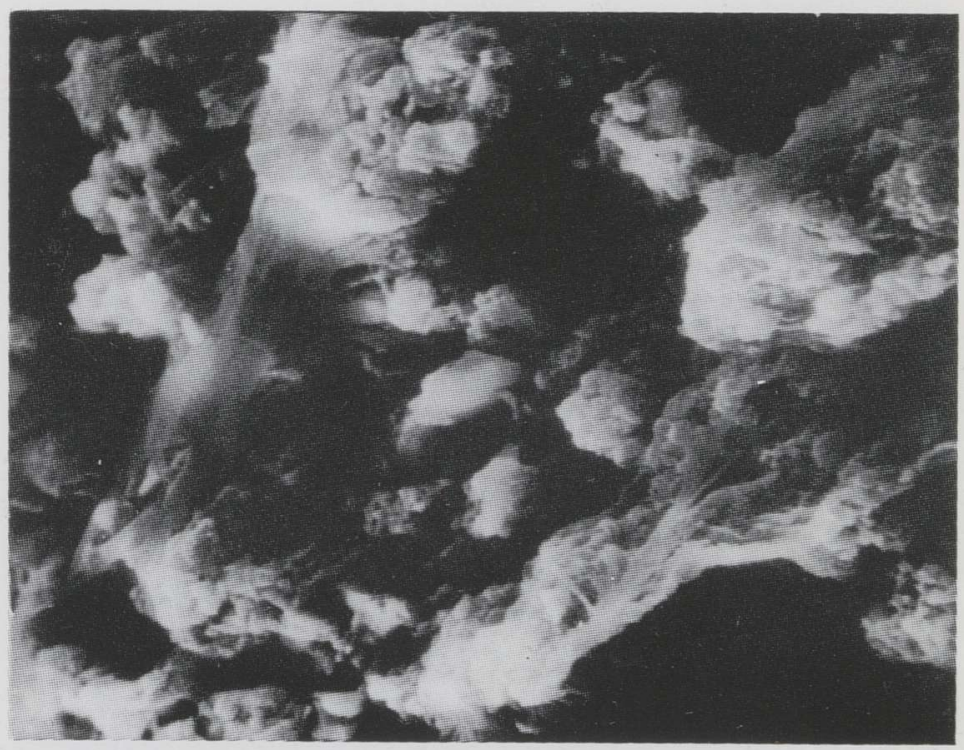

Fig. 8. Sample N104/2, SEM micrograph of an unetched broken surface of phosphatic cement in the basal conglomerate. Elongate phosphatized structures interpreted as possible microbial filaments. 


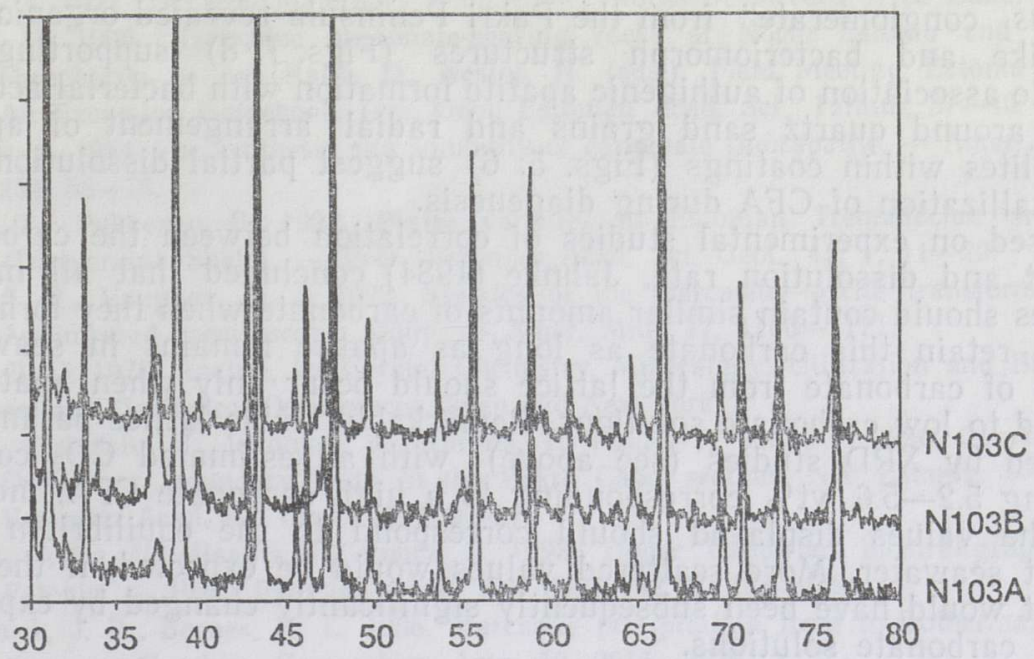

Angle of difiraction, $2 \Theta$

Fig. 9. XRD patterns of samples N103A, B, and C from the basal conglomerate on the Pakri Peninsula.

conglomerate is overlain by a bed of organic-rich shale, it seems plausible that the influx of the iron-reducing solutions into the pores of the conglomerate was a recurrent process. In an X-ray study of pyrite varieties from the Kallavere and Türisalu formations, Kallaste \& Pukkonen (1992) showed that a variety (referred to as variety 1) from sandstone interbeds within organic-rich shale has the mineral and chemical composition distinct from other varieties from different settings. We support their suggestion that the hydrogen sulphide solutions were likely produced (by sulphate reducing bacteria) in the beds of organic mud, from where the solution could migrate to the pores of the underlying sand beds, where a sequence of processes leading to pyrite formation took place. It seems likely that there occurred several phases of postsedimentary pyrite formation.

The interpretation of conditions of the formation of occasional marcasite occurrences detected by XRD remains open. Possible explanations include (1) occasional changes or anomalies in pore water chemistry that could lead to marcasite formation from solutions saturated with iron monosulphides or (2) superposed marcasite formation, possibly via overgrowth on pyrite.

Authigenic apatite formation in suboxic/anoxic sediments has been conventionally thought to occur by inorganic processes, e. g., diagenetically via direct precipitation, usually within organic muds in low oxygen environments (Slansky, 1986). However, recent evidence indicates that this might be a microbially mediated process (O'Brien et al., 1981; Froelich et al., 1988). One example of this is the subsurface trapping of phosphate beneath microbial mats colonizing the anoxic/oxic interface (Reimers et al., 1990). In this scenario phosphorus is released during organic matter degradation and diffuses upward until reaching the microbial mat, which acts as a seal to chemical diffusion, greatly reducing diffusion coefficients and resulting in elevated phosphate concentration in interstitial water and carbonate fluorapatite (CFA) precipitation. SEM studies of the 
"Obolus conglomerate" from the Pakri Peninsula revealed organic filament-like and bacteriomorph structures (Figs. 7, 8) supporting the possible association of authigenic apatite formation with bacterial activity. Films around quartz sand grains and radial arrangement of apatite crystallites within coatings (Figs. 5, 6) suggest partial dissolution and recrystallization of CFA during diagenesis.

Based on experimental studies of correlation between the carbonate content and dissolution rate, Jahnke (1984) concluded that all marine apatites should contain similar amounts of carbonate when they form and should retain this carbonate as long as apatite remains in seawater. A loss of carbonate from the lattice should occur only when apatite is exposed to low carbonate solutions. Remarkably stable lattice parameters revealed by XRD studies (see above), with an estimated $\mathrm{CO}_{3}$ content reaching 5.2-5.6 wt \% corresponding to a high carbonate CFA, indicate that the values displayed should correspond to the equilibrium with ancient seawater. More scattered values would be expected, if the $\mathrm{CO}_{3}$ content would have been subsequently significantly changed by exposure to low carbonate solutions.

\section{SUMMARY AND CONCLUSIONS}

The basal conglomerate of the Kallavere Formation on the Pakri Peninsula shows the features distinct from the conglomerates occurring at the base of the Kallavere Formation in the eastward sections. A very remarkable distinction is the presence of cobbles and blocks of the underlying Tiskre Formation in the conglomerate. Unlike most conglomerates, the studied conglomerate comprises mainly pebbles and cobbles, with a minority of lingulate shell fragments. These features can be interpreted as resulting from the denudation of the Lower Cambrian sandstones of the Tiskre Formation and their subsequent reworking to the conglomerate during the late Cambrian. As revealed by finds of Ungula sp. in some pebbles, the consolidated sediments formed during earlier transgressive phases of the late Cambrian, have also been reworked as pebbles to the conglomerate. The conodonts of the Cordylodus proavus Zone in the overlying beds (Mens et al., 1996) imply that the latest phase of conglomerate formation occurred not later than in the early Cordylodus proavus time. Authigenic minerals in cement indicate the prevalence of reducing environments in early diagenesis.

\section{ACKNOWLEDGEMENTS}

This study was supported by grant No. 949 of the Estonian Science Foundation. We are thankful to D. Kaljo, E. Pirrus, H. Bauert, K. Mens, and $\mathrm{T}$. Oja for the critical reading and correction of the manuscript.

\section{REFERENCES}

Berner, R. A. 1984. Sedimentary pyrite formation: An update. - Geochim. Cosmochim. Acta, 48, 605-615.

Froelich, P. N., Arthur, M. A., Burnett, W. C., Deakin, M., Hensley, V., Jahnke, R., Kaul, L., Kim, R.-H., Roe, K., Soutar, A., Vathakanon, C. 1988. Early diagenesis of organic matter in Peru continental margin sediments: Phosphorite precipitation. - Marine Geology, 80, 309-343. 
Hadding, A. 1927. The Pre-Quaternary Sedimentary Rocks of Sweden I, II. Lund.

Heinsalu, H. 1990. Tremadoc phosphate-bearing rocks of North Estonia and shelly phosphorite. - In: Kaljo, D., Nestor, H. (eds.). Field Meeting Estonia 1990. An Excursion Guidebook, Inst. Geol. Estonian Acad. Sci., Tallinn, 37-40.

Jahnke, R. A. 1984. The synthesis and solubility of carbonate fluorapatite. - Amer. J. Sci., $284,58-78$.

Kallaste, T., Pukkonen, E. 1992. Pyrite varieties in Estonian Tremadocian argillite (Dictyonema Shale). - Proc. Estonian Acad. Sci. Geol., 41, 1, 11-22.

Lennie, A. R., Vaughan, D. J. 1992. Kinetics of the marcasite-pyrite transformation: An infrared spectroscopic study. - Amer. Min., 77, 1166-1171.

McConnell, D. 1973. Apatite, Its Crystal Chemistry, Mineralogy, Utilization and Biological and Geological Occurrences. Wien and New York.

Mens, K., Heinsalu, H., Jegonjan, K., Kurvits, T., Puura, I., Viira, V. 1996. CambrianOrdovician boundary beds in the Pakri Cape section, NW Estonia. - Proc. Estonian. Acad. Sci. Geol., 45, 1, 9-21.

Mens, K., Viira, V., Paalits, I., Puura, I. 1993. Upper Cambrian biostratigraphy of Estonia. - Proc. Estonian Acad. Sci. Geol., 42, 4, 148-159.

Murowchick, J. B., Barnes, H. L. 1986. Marcasite precipitation from hydrothermal solutions. - Geochim. Cosmochim. Acta, 50, 2615-2629.

O'Brien, G. W., Harris, J. R., Milnes, A. R., Veeh, H. H. 1981. Bacterial origin of East Australian continental margin phosphorites. - Nature, 294, 442-444.

Puura, I., Holmer, L. 1993. Lingulate brachiopods from the Cambrian-Ordovician boundary beds in Sweden. - GFF, 115, 215-237.

Rakovan, J., Schoonen, M. A. A., Reeder, R. J., Tyrna, P., Nelson, D. O. 1995. Epitaxial overgrowths of marcasite on pyrite from the Tunnel and Reservoir Project, Chicago, Illinois, USA: Implications for marcasite growth. - Geochim. Cosmochim. Acta, 59, 2, 343-346.

Reimers, C. E., Kastner, R., Garrison, R. E. 1990. The role of bacterial mats in phosphate mineralization with particular reference to the Monterey Formation. - In: Burnett W. C., Riggs S. R. (eds.). Phosphate Deposits of the World, Cambridge Univ. Press, 300-311.

Schoonen, M. A. A., Barnes, H. I. 1991a. Reactions forming pyrite and marcasite from solution: I. Nucleation of $\mathrm{FeS}_{2}$ below $100^{\circ} \mathrm{C}$. - Geochim. Cosmochim. Acta, 55, 1495-1504.

Schoonen, M. A. A., Barnes, H. I. 1991b. Reactions forming pyrite and marcasite from solution: II. Via FeS precursors below $100^{\circ} \mathrm{C}$. - Geochim. Cosmochim. Acta, $55,1505-1514$.

Schuffert, J. D., Kastner, R., Emanuele, G., Jahnke, R. A. 1990. Carbonate-ion substitution in francolite: A new equation. - Geochim. Cosmochim. Acta, 54, 23232328.

Slansky, M. 1986. Geology of Sedimentary Phosphates. Studies in Geology. - North Oxford Academic Publishers, London.

Мююрисепп К. К. 1958. Характеристика нижней границы пакерортского горизонта от мыса Пакерорт до реки Сясь. - Тр. Ин-та геол. АН ЭССР, III, 55-79.

Попов Л. Е., Хазанович К. К., Боровко Н. Г., Сергеева С. П., Соболевская Р. Ф. 1989. Опорные разрезы и стратиграфия кембро-ордовикской фосфоритоносной оболовой толщи на северо-западе Русской платформы. Наука, Ленинград.

Хейнсалу Х. 1987. Литостратиграфическое расчленение тремадокских отложений Северной Эстонии. - Изв. АН ЭССР. Геол., 36, 2, 66-78. 


\title{
KALLAVERE KIHISTU BASAALKONGLOMERAAT (ULEMKAMBRIUM) PAKRI POOLSAAREL
}

Jüri NEMLIHER, Ivar PUURA

Pakri poolsaarel lasuvad kuni poole meetri paksused Kallavere kihistu basaalkonglomeraadi läätsed alamkambriumi Tiskre kihistu liivakividel. Lingulaatide Ungula convexa ja $U$. ingrica leiud konglomeraadis ning Cordylodus proavus'e biotsooni konodontide esinemine lasuvates Kallavere kihistu kivimites viitavad konglomeraadi kujunemisele hiliskambriumis. Konglomeraadis sisalduvad veerised pärinevad valdavalt lamavast Tiskre kihistust, kuid ka ülemkambriumi ümbertöötatud kivimitest. Konglomeraadi tsemendis sisalduvad autigeensed mineraalid: apatiit, püriit ning markasiit viitavad valdavalt sulfaatredutseerivatele tingimustele varadiageneesi etapil.

\section{ВЕРХНЕКЕМБРИЙСКИИ БАЗАЛЬНЫЙ КОНГЛОМЕРАТ КАЛЛАВЕРЕСКОЙ СВИТЫ НА ПОЛУОСТРОВЕ ПАКРИ, СЕВЕРО-ЗАПАДНАЯ ЭСТОНИЯ}

\author{
Юри НЕМЛИХЕР, Ивар ПУУРА
}

На п-ове Пакри базальный конгломерат каллавереской свиты мощностью до 0,5 м залегает на нижнекембрийской тискреской свите. Конгломерат содержит остатки лингулат и гальку из подстилающих песчаников тискреской свиты, а также из переработанных верхнекембрийских пород. По находкам брахиопод Ungula convexa и U. ingrica в конгломерате и конодонтов зоны Cordylodus proavus в надстилающих песчаниках каллавереской свиты установлен верхнекембрийский возраст конгломерата. Аутигенные минералы - апатит, пирит и марказит - указывают на преимущественно восстановительные условия в раннем диагенезе. 